\title{
PARTISIPASI MASYARAKAT DALAM MENINGKATKAN PENDIDIKAN DI LEMBAGA PENDIDIKAN ANAK USIA DINI (PAUD)
}

\section{Shinta HAD Yusup}

PAUD Al Furqon

\author{
yusufshintahad@gmail.com
}

\begin{abstract}
ABSTRAK
Minimnya sumber daya manusia dan kurangnya sosialisasi pemerintah terhadap masyarakat yang ada di daerah terkait dengan Pendidikan Anak usia dini dikhawatirkan akan berdampak pada tingkat partisipasi masyarakat terhadap Pendidikan Anak usia dini, padahal Pendidikan Anak usia dini akan mampu membentuk anak berkualitas; anak bertumbuh kembang sesuai dengan tahapannya sehingga akan siap memasuki pendidikan selanjutnya.Penelitian ini bertujuan untuk mengetahui partisipasi masyarakat dan faktor pendukung dan faktor penghambat dalam pelaksanaan program PAUD Al-Furqon Desa Weninggalih Sindangkerta. Metode yang penulis gunakan dalam penelitian ini adalah Metode Analisis Deskriptif dengan pendekatan kualitatif. Adapun hasil penelitian ini menunjukan bahwa partisifasi masyarakat terhadap Pendidikan Anak usia dini menunjukan tingkat yang cukup menggembirakan. Hal tersebut didorong oleh pemahaman pentingnya pelaksanaan pendidikan usia dini yang tinggi. Partisipasi mereka ditunjukan dalam bentuk kebermitraan dengan PAUD Al Furqon dengan aktif, penghubung lembaga PAUD dengan rumah, menjadi penyokong PAUD Al Furqon, terlibat aktif bersama tenaga pendidik dan pengelola PAUD dan pendukung tujuan pendidikan, sekaligus sebagai penerima manfaat pendidikan. Bentuk lainnya diantaranya ialah menjadi motivator bagi para orang tua, menyumbangkan berbagai sumber daya, dan ikut meningkatkan mutu PAUD Al Furqon.
\end{abstract}

Kata Kunci: Pendidikan Usia Dini, Anak, Masyarakat

\section{PENDAHULUAN}

Lembaga Pendidikan merupakan tempat memperoleh pengetahuan dan keterampilan yang diterima oleh masyarakat tertentu. Di sisi lain, pembangunan bangsa adalah implementasi proses yang diarahkan untuk mengkomposisi kembali lembaga-lembaga negara sehingga mereka dapat mencerminkan keinginan, kebutuhan, dan aspirasi masyarakat yang lebih luas. Pendidikan merupakan prasyarat penting bagi pembangunan bangsa karena semakin banyak orang yang menjadi tercerahkan semakin mereka menahan diri dari melakukan praktik yang akan membahayakan upaya pembangunan bangsa. Dewasa ini kita hidup di dunia dengan perkembangan informasi dan pengetahuan yang sangat pesat sehingga menempatkan pendidikan pada posisi paling penting bagi setiap keluarga, komunitas, dan bangsa. Kita harus menjaganya dan mengembangkannya untuk pembangunan sosial ekonomi. Kualitas pendidikan berarti pertumbuhan dan perkembangan intelektual, emosional, spiritual, dan sosial. 
Pendidikan adalah bagian penting dalam sebuah kemajuan bangsa. Maju atau mundurnya sebuah bangsa tergantung sejauhmana tata kelola pendidikan bangsa tersebut. Pendidikan dalam pelaksanaannya menjadi tanggung jawab bersama yang dilaksanakan oleh seluruh komponen bangsa dan negara. Dalam keberlangsungannya masyarakat sejak lama telah berkontribusi signifikan merintis dan mengembangkan pendidikan di tanah air. Lembaga pendidikan, baik yang di bawah naungan komunitas sosial, organisasi masyarakat maupun yayasan telah memberikan sumbangan dalam membangun bangsa dan negara dengan jalur pendidikan.

Masa kanak-kanak adalah tahap kehidupan yang sangat penting dalam hal perkembangan fisik, intelektual, emosional dan sosial seorang anak. Perubahan terjadi pula pada softskills anak mengenai kemampuan berpikir dan berbicara yang lebih rumit pada lingkungan heterogen (Firmansyah, 2018). Pertumbuhan kemampuan mental dan fisik berkembang pada tingkat yang mencengangkan dan proporsi pembelajaran yang sangat tinggi terjadi sejak lahir hingga usia enam tahun. Ini adalah saat ketika anakanak sangat membutuhkan pelayanan pribadi dan pengalaman belajar yang berkualitas tinggi.

Pendidikan dimulai dari saat anak dilahirkan dan berlanjut ketika anak mulai menghadiri lingkungan anak- anak sebaya. Kemampuan belajar manusia terus berlanjut selama sisa hidup mereka tetapi tidak pada intensitas yang ditunjukkan di tahun-tahun prasekolah. Dengan demikian bayi dan balita memerlukan pengalaman belajar awal yang positif untuk mendorong perkembangan intelektual, sosial dan emosional mereka dan ini meletakkan dasar untuk kesuksesan sekolah di kemudian hari.

Partisipasi masyarakat dalam mengembangkan program Pendidikan Anak ussia dini ialah suatu upaya mengikutsertakan masyarakat dalam perencanaan, pelaksanaan dan pengawasan serta monitoring dan evaluasi pendidikan. Hal ini sesuai dengan UU Sisdiknas Nomor 20 Tahun 2003, pasal 8 yang menyatakan bahwa masyarakat berhak berperanserta dalam perencanaan, pelaksanaan, pengawasan dan evaluasi program pendidikan. Partisipasi masyarakat dalam mengembangkan program pendidikan ini diharapkan mampu meningkatkan mutu pendidikan secara menyeluruh yang bermuara pada peningkatan mutu Sumber Daya Manusia Indonesia.

Desa Weninggalih termasuk desa tertinggal yang minim Sumber Daya Manusia (SDM). Umumnya masyarakat yang menempati wilayah seluas $14.78 \mathrm{KM}^{2}$ ini hanya lulusan SD dengan tingkat penghasilan yang rendah. Hal ini diperparah dengan fasilitas kesehatan yang jauh dari pusat- pusat penduduk yang berjumlah 5.952 jiwa (BPS Bandung Barat, 2016). Hal ini menjadi tantangan tersendiri dalam sosialisasi dan peningkatan kualitas pendidikan anak ussia dini seperti yang dikehendaki oleh pemerintah.

Sadar akan hal tersebut tokoh masyarakat di lingkunga Desa Weninggalih terpanggil untuk mendirikan lembaga pendidikan yang khusus menyelenggarakan kegiatan Pendidikan Usia Dini dengan harapan dapat memberikan sumbangan pada peningkatan SDM di lingkungan setempat. Hal tersebut tidak hanya melibatkan aspek- aspek pendidikan normatif semata, melainkan juga menuntut kesadaran dan partisipasi masyarakat untuk mencapai tujuan- tujuan lembaga tersebut karena sudah barang tentu bahwa nanti masyarakat sendirilah yang akan menikmati hasil dari pendidikan 
yang diselenggarakan. Di sini lah titik strategis pelibatan masyarakat dalam mendirikan dan mengembangkan pendidikan usia dini di lingkungannya sendiri.

\section{KAJIAN TEORI}

Dewasa ini pendidikan di Indonesia menghadapi tiga tantangan besar. Pertama, sebagai akibat dari krisis global yang melanda dunia ketiga, termasuk Indonesia, menuntut pendidikan untuk berubah menyesuaikan diri dengan perkembangan masyarakat dunia. Kedua,mengantisipasi perubahan tersebut pendidikan dituntut untuk menyiapkan sumber daya manusia yang mampu bersaing guna menghadapi era globalisasi. Ketiga, sejalan dengan berlakunya otonomi daerah, dengan maksud untuk memaksimalisasi potensi daerah demi kepentingan bersama, perlu dilakukan perubahan dan penyesuaian arah pendidikan nasional sehingga dapat mewujudkan proses pendidikan yang demokratis, memperhatikan keragaman dan keadaan daerah, yang pada akhirnya mendorong partisipasi masyarakat. Namun demikian, pada prakteknya lembaga pendidikan seringkali mendapat kritikan yang serius. Disinyalir sekolah selama ini menjadi alat penjinakan yang memanipulasi perserta didik agar mereka dapat diperalat untuk melayani kepentingan kelompok yang berkuasa.

Dari uraian singkat tersebut nampak jelas signifikansi dan urgensi partisipasi masyarakat dalam pendidikan sehingga diharapkan terjadinya proses pendidikan yang demokratis, menghargai keragaman, meningkatkan kompetensi sumberdaya manusia, menggali potensi kedaerahan, sekaligus pendidikan menjadi pemersatu bangsa. Terkikisnya sekat- sekat pembatas antar kelompok sosial dan pemerkuatan kohesifitas masyarakat sejatinya menjadi bagian dari puncak keberhasilan pendidikan. Oleh karena itu pendidikan seyogianya tidak hanya terjadi pada ruang- ruang formal saja, melainkan juga terjadi dalam setiap tempat dan kesempatan; menjadi manusia pembelajar. Hal ini pula lah yang kemudian menjadi salah satu dasar dari konsep pendidikan luar sekolah.

Pendidikan Luar Sekolah adalah setiap kesempatan berkomunikasi yang terencana di luar sekolah di mana seseorang mendapatkan informasi, pengetahuan, latihan maupun bimbingan sesuai dengan perkembangannya dengan tujuan mengembangkan keterampilan, sikap dan nilai-nilai yang menjadikannya personal yang efektif dan efisien di keluarga, profesi, dan masyarakat. Combs berpendapat bahwa Pendidikan Luar Sekolah adalah proses pendidikan terorganisir yang diselenggarakan secara non formal, baik dilaksanakan tersendiri maupun menjadi bagian dari pelaksanaan suatu kegiatan makro, dengan maksud untuk memberikan layanan pendidikan kepada peserta didik dalam mencapai tujuan-tujuan belajar (Direktorat PAUD, 2006).

Adapun jenis- jenis Pendidikan Luar Sekolah yang terdapat di Indonesia ialah Pendidikan Orang Dewasa, Pendidikan Anak ussia dini, Pendidikan Life Skills, Pendidikan Kesetaraan, Pendidikan Seumur Hidup, dan Pendidikan Keaksaraan. Berkaitan dengan pendidikan anak ussia dini sebagai salah satu bentuk Pendidikan Luar Sekolah sesungguhnya telah diatur dalam UU Sisdiknas pasal 1 ayat 14 Nomor 20 tahun 2003. Negara sangat serius memperhatikan kegiatan pendidikan anak ussia dini karena kelak pendidikan jenis ini akan menjadi dasar sekaligus bekal bagi anak untuk melanjutkan pendidikan ke jenjang berikutnya.

Pendidikan sejatinya menjadi kunci bagi sebuah kemajuan bangsa. Tanpa pendidikan yang baik sebuah bangsa dan negara tidak akan maju dan berkembang dengan baik. 
Dalam konteks keberlangsungannya, pendidikan tidak hanya dirintis dan dilaksanakan oleh pemerintah, akan tetapi masyarakat dari sejak dahulu telah menunjukan peran besar dalam merintis dan melaksanakan pendidikan di tanah air. Bahkan jauh sebelum kemerdekaan lembaga pendidikan baik yang di bawah naungan komunitas sosial, ormas maupun yayasan telah berkontribusi dalam membangun bangsa dan negara melalui pendidikan.

Anak-anak yang belajar pada usia dini biasanya mengalami peningkatan keterampilan sosial, pengetahhuan akademik dan sikap yang baik pada fase berikutnya dalam perkembangan hidupnya. Oleh karena itu penyelenggaraan pendidikan anak ussia dini penting dilaksanakan dengan mengikutsertakan seluruh stakeholder yang bekerjasama dalam menjalankan dan mencapai tujuan pendidikan secara bersama- sama.

Partisipasi masyarakat dalam mengembangkan Pendidikan Anak ussia dini merupakan usaha melibatkan mereka dalam proses penyelenggaraan pendidikan dari mulai perencanaan hingga evaluasi pendidikan. Hal ini berarti bahwa masyarakat ikut terlibat dalam keputusan dengan bentuk penyampaian saran dan pendapat. Partisipasi dapat juga bermakna bahwa masyarakat mengenal masalah mereka sendiri, memecahkan masalahnya, mengkaji pilihan mereka, dan mengambil keputusan. Keterlibatan masyarakat dalam mengembangkan Pendidikan Usia Dini pada gilirannya akan melahirkan rasa memiliki dan tanggungjawab masyarakat terhadap kemajuan pendidikan itu sendiri dan sekaligus menjadikan masyarakat sebagai salah satu pusat pendidikan.

Atomoko berpendapat (Atmoko, 2009) bahwa partisipasi dalam perkembangannya memiliki pengertian yang beragam. Dalam kultur demokratis setidaknya terdapat tiga tradisi partisipasi, yaitu partisipasi politik, partisipasi sosial dan partisipasi masyarakat. Ia menambahkan bahwa dalam hal ini partisipasi sosial posisinya berada diluar lembaga formal. Sedangkan partisipasi masyarakat diartikan sebagai perhatian masyarakat dalam pembuatan kebijakan dan pengambilan keputusan di berbagai dimensi yang sejatinya akan mempengaruhi kehidupan mereka.

Bentuk-bentuk partisipasi tersebut menurut Sastroputro (Sastroputro, 1989) membagi 5 bentuk partisipasi, yaitu (1) Partisipasi buah pikiran, (2) Partisipasi keterampilan, (3) Partisipasi tenaga, (4) Partisipasi uang, dan (5) Partisipasi harta benda. Penyelenggaraan pendidikan bukan hanya tugas bagi pemerintah semata, akan tetapi masyarakat memiliki andil dalam memajukan pendidikan. Hal itu diperkuat dalam UU Sisdiknas Nomor 20 Tahun 2003, Pasal 8 yang menyatakan bahwa masyarakat berhak terlibat dalam perencanaan, pelaksanaan, pengawasan, dan evaluasi program kerja di bidang pendidikan. Pasal berikutnya menyatakan bahwa masyarakat berkewajiban memberikan dukungan sumber daya dalam penyelenggaraan pendidikan.

Menurut Berger, seperti dikutif Styarini dalam bukunya, terdapat sekurangnya enam macam bentuk partisipasi orangtua dalam PAUD, yaitu 1) Mitra kerja yang aktif dengan sekolah, 2) Penyokong sekolah untuk mencapai prestasi pendidikan yang unggul, 3) Terlibat aktif bersama tenaga sukarela, 4) Penghubung antara sekolah dan rumah, 5) Pendukung tujuan pendidikan, 6) Penerima pendidikan (Styarini, 2004). Adapun tokoh masyarakat bisa berpartisipasi dalam bentuk motivasi social dan penyumbang sumberdaya. 


\section{METODE}

Metode penelitian yang digunakan penulis dalam penelitian ini adalah metode penelitian analisis deskriptif dengan pendekatan kualitatif. (Sugiyono, 2008) Metode ini menjadi prosedur pemecahan masalah yang diteliti dengan menjabarkan keadaan subjek/ objek penelitian pada saat ini berdasarkan fakta-fakta yang tampak di lapangan atau sebagaimana adanya.

Peneletian ini dilakukan di lingkungan PAUD Al Furqon Desa Weninggalih Kecamatan Sindangkerta Kabupaten Bandung Barat. Yang menjadi informan dalam penelitian ini berjumlah 8 orang yang terdiri dari 5 orangtua siswa dan 3 orang tokoh masyarakat. Guna memperoleh data yang diperlukan dalam penelitian ini penulis menggunakan teknik observasi, wawancara dan dokumentasi. Selanjutnya, setelah data terkumpul penulis melakukan tahapan reduksi data, penyajian data, dan penarikan kesimpulan.

\section{HASIL DAN PEMBAHASAN}

\section{HASIL}

a. Pemahaman Masyarakat Tentang Anak ussia dini :

1) Anak ussia dini adalah anak usia prasekolah yang harus dibimbing dan diarahankan oleh orangtua.

2) Anak ussia dini merupakan usia anak yang sangat memerlukan perhatian, kasih sayang, pembiasaan dan tauladan dari orangtua dalam menumbuhkan bakat dan mengembangkan potensi yang dimilikinya.

3) Anak ussia dini adalah peniru terbaik. Oleh karena itu ia harus diberikan contoh dan bimbingan yang baik dari keluarga dan lingkungannya.

b. Pemahaman Masyarakat Tentang Pendidikan Anak ussia dini :

1) Pendidikan Anak ussia dini merupakan pendidikan yang wajib diberikan kepada anak sehingga anak dapat menjadi sehat, cerdas, terampil dan tumbuh dengan baik.

2) Pendidikan Anak ussia dini diberikan dengan cara bermain gembira sambil belajar dan bersosialisasi sehingga diharapkan anak dapat mengembangkan potensinya dengan sempurna dan mampu hidup bersama dengan lingkungan sosialnya.

3) Pendidikan Anak ussia dini harus dilaksanakan secara serius sebagai bekal awal untuk melanjutkan ke jenjang pendidikan berikutnya.

c. Pemahaman Masyarakat Tentang Manfaat Pendidikan Anak ussia dini :

1) Dapat menumbuhkembangkan secara optimal potensi anak

2) Dapat menjadikan anak sehat, cerdas, terampil dan santun.

3) Dapat menjadi wahana sosialisasi anak ussia dini untuk bersosialisasi setelah lingkungan rumah

d. Partisipasi Orangtua terhadap PAUD Al Furqon

e. Pelaksanaan Pendidikan Anak ussia dini di rumah :

1) Orangtua membiasakan berbagai hal kepada anak sejak bangun tidur hingga tidur lagi.

2) Anak dibiasakan tidur lebih awal agar durasi tidur ideal tercapai untuk menjaga kesehatannya.

3) Membiasakan anak bangun bersama orangtua

4) Memandikan anak setelah bangun

5) Melatihkan anak menggosok gigi

6) Mengajari anak cara memakai baju dengan benar

7) Membiasakan anak untuk sarapan sambil diajak berbicara dan atau bercerita 
8) Memberi susu anak

9) Mengantar anak ke PAUD

10)Jika sedang sibuk anak diantar oleh saudara atau neneknya

11)Mengajari anak bernyanyi, membaca doa pendek, mengucap salam dan mencium tangan orang yang lebih tua.

f. Alasan Memasukkan Anak ke PAUD Al Furqon:

1) Agar anak menjadi pandai dan terampil

2) Agar anak dapat mengembangkan minat dan bakatnya

3) Agar anak tumbuh cerdas dan pintar

4) Agar anak memiliki sopan santun

g. Faktor Pendukung dan Faktor Penghambat PAUD AL Furqon

1) Faktor pendukung : Tingkat pemahaman orangtua dan masyarakat terhadap PAUD yang lebih baik dan Peranserta orangtua dan masyarakat dalam PAUD.

2) Faktor penghambat : Biaya menyertakan anak ke PAUD dan Kesibukan orangtua.

h. Bentuk- Bentuk Partisipasi Masyarakat Terhadap PADU Al Furqon

1) Mitra kerja yang aktif dengan PAUD Al Furqon Orangtua berkomunikasi pengelola PAUD Al Furqon terkait perkembangan anak didiknya, mengikuti rapat- rapat, dan memberi masukan kepada pihak pengelola PAUD Al Furqon demi majunya lembaga pendidikan tersebut.

2) Penghubung sekolah dengan rumah

Orangtua ikut mengamati selama proses pembelajaran di PAUD sambil menunggu waktu pulang. Jika orangtua tidak mendampingi anak ke PAUD Al Furqon, biasanya nanti akan ditanyakan kegiatan anak kepada yang mengantarnya. Mereka senantiasa menemani sambil mengamati perilaku anak sewaktu di rumah, mengajak anak untuk bermain saat tidak ada temannya. Kadang- kadang anak ditemani neneknya saat bermain.

Mereka juga Mengevaluasi kegiatan di PAUD Al Furqon dengan menanyakan aktivitas selama disana, melakukan pengulangan terhadap apa yang dilakukan di PAUD dan bertukar cerita dengan pengelola/ guru/ tutor terkait hambatanhambatan ketika anak belajar. Singkatnya orangtua dan pendidik menjadi tim dalam pendidikan anak.

3) Penyokong sekolah untuk mencapai prestasi yang unggul

Orangtua selalu tepat waktu dalam membayar sekolah anak. Dalam kondisi tertentu sebagian orangtua terlambat membayar uang sekolah keuangan sedang minim. Walaupun kondisi uang sedang minim, orangtua telah menyisihkan uangnya untuk anak sehingga tetap tetap waktu membayarnya. Membayar tabungan wajib tiap bulan, memberikan bantuan lain bersama dengan orangtua murid lainnya melalui iuran untuk kegiatan, membayar iuran untuk membeli alat peraga, dan memberikan sumbangan sukarela

4) Terlibat aktif bersama tenaga sukarela

Orangtua bersinergi dengan pengelola, tutor dan relawan yang ada di PAUD Al Furqon

5) Pendukung tujuan pendidikan

Orangtua memenuhi keperluan pendidikan anak, seperti membeli buku, alat peraga dan pakaian seragam anak. Selain itu mereka memberikan motivasi kepada anak untuk rajin belajar, dan merayu anak ketika malas pergi ke PAUD Al Furqon.

6) Penerima Pendidikan 
Orangtua berharap PAUD Al Furqon dapat mewujudkan anak didik yang sehat, terampil, cerdas dan berkarakter, serta bisa menjadi tahap awal untuk melanjutkan ke jenjang berikutnya.

Secara khusus bentuk- bentuk partisipasi tokoh masyarakat kepada PAUD Al Furqon diantaranya:

1) Memberikan motivasi kepada masyarakat untuk melaksanakan Pendidikan Usia Dini di rumah dan di lembaga- lembaga Pendidikan Anak ussia dini seperti PAUD Al Furqon.

2) Menjadi kontributor utama pada sumberdaya.

3) Terlibat dalam peningkatan mutu pendidikan PAUD Al Furqon

\section{PEMBAHASAN}

Selama tiga tahun pertama seorang anak, orang tua menjadi pengaruh utama dalam pengalaman belajar dan pendidikan anak. Apa yang orang tua lakukan dan berdampak pada anak-anak mereka pada perkembangan selanjutnya. Orangtua terkadang lupa bahwa orang tua memiliki dampak yang luar biasa terhadap pendidikan anak-anak pada usia berapapun. Jika orang tua memilih untuk berpartisipasi dalam kelompok Ibu dan Balita atau lembaga PAUD, memiliki potensi untuk memberikan pengalaman berkualitas tinggi, individual, responsif, dan rangsangan yang akan mempengaruhi pengalaman belajar anak. Dengan pemikiran ini, seorang anak dalam lingkungan negatif juga bisa mengakibatkan efek negatif juga. Fakta ini membuat penting bahwa lingkungan tempat anak ditempatkan selama tahun-tahun awal ini menjadi positif. Hubungan yang sangat kuat tertanam dalam rutinitas sehari-hari yang disediakan oleh lembaga pendidikan anak usia dini menjadi utama dalam kehidupan anak. Termasuk sejak anak masih berada di lingkungan keluarga, penanaman nilai-nilai kehidupan menjadi sangat penting untuk membentuk karakter anak di masa yang akan datang (A.S. Akhyadi dan D. Mulyono, 2018).

Partisipasi keluarga sangat diperlukan dalam pendidikan anak ussia dini. Hal ini disebabkan oleh proses awal anak belajar dimulai dari lingkungan keluarga. Pendidikan anak ussia dini sebagai aspek penting dalam Rencana Strategis (Renstra) pembangunan sumber daya manusia Indonesia menjadi fundamental dan signifikan bagi pembangunan. Oleh karen itu penumbuhan dan pengembangan pendidikan anak usi dini secara terencana dan terprogram dengan melibatkan orangtua dan masyarakat adalah suatu keniscayaan (Siswanto, 1994). Penelitian ini menunjukan bahwa pemahaman dan kesadaran masyarakat terhadap PAUD telah tumbuh dengan baik. Para orangtua memiliki pandangan bervariasi terhadap anak ussia dini dan PAUD. Namun dapat diperoleh gambaran bahwa dalam pandangan mereka bahwa anak ussia dini adalah anak di bawah usia 6 tahun yang perlu diberi perhatian, kasih sayang dan dibimbing oleh orangtua sehingga anak tumbuh dan berkembang dengan baik sebagai fundamen memasuki fase usia berikutnya. Meskipun pendapat masyarakat bervariasi namun mereka cukup memahami tentang anak ussia dini seperti yang dikatakan oleh Netti Herawati (Herawati, 2005) bahwa anak ussia dini merupakan golden age seorang anak; masa peletakan pondasi kecerdasan manusia, masa pengembangan dan pembentukan kemampuan kognitif, bahasa, seni, sosial, emosional, moral dan nilai-nilai agama.

Peran utama orangtua sebagai guru pertama bagi anak sangat penting dipahami oleh orangtua. Proses pembiasaan yang dilakukan di rumah akan terbawa hingga mereka 
dewasa. Misalnya, otang tua membiasakan anaknya untuk tidur lebih awal agar bisa bangun lebih awal juga. Adapun jika anak susah tidur, mereka punya cara yang bervariasi agar anak bisa tidur. Ada sebagian orangtua yang memberikan susu dan makanan dan ada pula yang membacakan cerita. Meskipun cara yang dilakukan berbeda, namun prinsipnya para orangtua selalu selalu membujuk anaknya agar tidur tidak terlambat.

Setiap pagi mereka memandikan anak- anaknya sembari mengajari bagaimana cara menggosok gigi dengan benar. Mereka mengganti pakaian anaknya setelah mandi. Sebagian dari mereka mulai mengajari anak cara berpakaian yang benar. Ibrahim GJ (GJ, 1982) menyatakan bahwa fungsi biologi keluarga bagi anak antara lain adalah pemberian makan bergizi dan perawatan kesehatan. Berdasarkan hasil penelitian, para orangtua di Desa Weninggalih telah menjalankan fungsi tersebut secara rutin dengan baik.

Selain fungsi biologi tersebut, fungsi orangtua dalam keluarga adalah sebagai fungsi agama. Oleh karena itu orangtua sejatinya mulai mengenalkan , mengajarkan dan membiasakan perilaku kagamaan kepada anaknya sejak kecil. Berdasarkan hasil penelitian ini menunjukan bahwa para orangtua di Desa Weninggalih umumnya telah mengenalkan dan mengajarkan anaknya agama sejak dini. Hal tersebut dilakukan dengan mengajarkan dan membiasakan anaknya membaca doa dalam aktivitas rutin harian mereka, mengucap salam dan juga mencium tangan orang yang lebih tua.

Terdapat sekurangnya enam macam bentuk partisipasi orangtua dalam PAUD (Styarini, 2004), yaitu kebermitraan dengan PAUD Al Furqon dengan aktif, penghubung lembaga PAUD dengan rumah, menjadi penyokong PAUD Al Furqon, terlibat aktif bersama tenaga pendidik dan pengelola PAUD dan pendukung tujuan pendidikan, sekaligus sebagai penerima manfaat pendidikan. Bentuk lainnya diantaranya ialah menjadi motivator bagi para orang tua, menyumbangkan berbagai sumber daya, dan ikut meningkatkan mutu PAUD Al Furqon. Hal tersebut seluruhnya sudah dilakukan oleh orangtua.

Adapun bentuk partisipasi tokoh masyarakat dalam penyelenggaraan PAUD (Sudjiono, 2009):

1) Motivator

Dalam hal ini, para tokoh masyarakat berperan untuk memberikan informasi yang berkaitan dengan penyelenggaraan program Pendidikan Anak ussia dini kepada para orangtua untuk memotivasi mereka agar ikut berpartisipasi aktif dalam penyelenggaraan Pendidikan Anak ussia dini. Hal ini dilakukan dalam bentuk sosialisasi program. Berdasarkan hasil penelitian, para tokoh masyarakat telah memotivasi orangtua dengan bersosialisasi tentang pentingnya Pendidikan Anak ussia dini untuk merangsang kesadaran orangtua agar berpartisipasi dalam PAUD Al Furqon. Ada sebagian dari tokoh masyarakat yang bekerjasama dengan tokoh masyarakat lainnya untuk memberi motivasi tersebut. Ketua PKK, selalu mengingatkan para orangtua tentang PAUD melalui pertemuan PKK dan juga Posyandu.

Beberapa faktor yang dialami tokoh masyarakat dalam kegiatan sosialisasi tersebut diantaranya: a). Faktor pendukung, yaitu adanya respon yang baik dari para orangtua. 
b). Faktor penghambat, yaitu untuk pertama kali melakukan sosialisasi masih kurangnya kesadaran dari orangtua untuk mengikutinya.

2) Menyumbangkan sumber daya

Para tokoh masyarakat memberikan sumbangan kepada PAUD baik berupa sumbangan dana maupun sumbangan yang lainnya. Berdasarkan hasil penelitian, beberapa sumbangan telah diberikan oleh tokoh masyarakat kepada PAUD Al Furqon, baik yang berupa sumbangan dana, sumbangan tenaga, dan sumbangan fasilitas., serta turutserta dalam upaya meningkatkan mutu PAUD Al Furqon.

\section{SIMPULAN}

Partisipasi masyarakat terhadap PAUD menunjukan tingkat yang cukup menggembirakan. Hal tersebut didorong oleh pemahaman mereka terhadap pentingnya pelaksanaan PAUD yang tinggi. Partisifasi mereka dalam penyelenggaraan PAUD Al Furqon Desa Weninggalih Kecamatan Sindangkerta Kabupaten Bandung Barat dilakukan dalam bentuk mitra kerja yang aktif, menjadi penghubung PAUD Al Furqon dengan rumah, menjadi penyokong PAUD Al Furqon untuk mencapai prestasi pendidikan yang unggul, terlibat aktif bersama tenaga pendidik dan pengelola PAUD, pendukung tujuan pendidikan, dan sebagai penerima pendidikan. Bentuk lainnya diantaranya ialah menjadi motivator bagi para orang tua, menyumbangkan berbagai sumber daya, dan ikut meningkatkan mutu PAUD Al Furqon. Adapun kendala yang dihadapi PAUD Al Furqon diantaranya menyangkut persoalan pembiayaan yang masih terbatas, fasilitas dan media belajar yang masih perlu dilengkapi, dan tenaga pendidik yang sebagian belum memenuhi kualifikasi pendidik PAUD.

Dari simpulan penelitian ini penulis dapat merekomendasikan beberapa hal, baik kepada lembaga PAUD Al Furqon maupun kepada masyarakat setempat, yakni: Pertama, hendakanya PAUD Al Furqon menggali sumber- sumber anggaran pembiayaan PAUD secara kreatif sehingga seluruh kebutuhan pelaksanaan dan peningkatan mutu pendidikan bisa terpenuhi secara memadai. Kedua, dalam melengkapi fasilitas dan media belajar hendaknya PAUD Al Furqon mampu mengoptimalkan sumber daya yang ada di lingkungan setempat. PAUD Al Furqon bisa membuat sendiri fasilitas dan media belajar dari bahan- bahan yang terdapat di lingkungan PAUD berdiri yang tentu akan mereduksi biaya pengiriman dan produksi. Ketiga, mendorong tenaga pendidik yang sudah ada di PAUD Al Furqon untuk melanjutkan kuliah agar kualifikasi pendidik dapat terpenuhi. Hendak pula PAUD Al Furqon mencarikan peluang- peluang beasiswa atau orangtua angkat guna meringankan beban biaya kuliah bagi pendidik yang sudah bekerja di tempat tersebut. Keempat, hendaknya masyarakat berpartisipasi dengan cara- cara yang lebih intens, kreatif dan menyeluruh guna mendukung keberlangsungan proses pendidikan di PAUD Al Furqon. Peran penting masyarakat dalam sistem pendidikan PAUD diantaranya untuk mengatasi masalah manajemen. Misalnya dalam proses penilaian pembelajaran berbasis sekolah tidak termasuk data tentang prestasi belajar siswa yang cenderung sering tidak masuk sekolah atau anak-anak usia sekolah yang tidak terdaftar, sehingga memberikan gambaran sebagian tentang hasil pembelajaran di sekolah. Penilaian semacam ini sering dikumpulkan setelah mengelola penilaian di sekolah tanpa analisis atau umpan balik berbasis sekolah untuk menarik beberapa implikasi praktis untuk strategi pedagogis dan manajerial lebih lanjut di tingkat sekolah. Evaluasi pendidikan cenderung dianggap sebagai masalah profesional dan kebijakan, dikelola oleh pejabat pemerintah dengan meninggalkan pemangku 
kepentingan lainnya termasuk orang tua, anggota masyarakat, dan siswa sebagai penerima manfaat tunggal.

\section{DAFTAR PUSTAKA}

Akhyadi, A. S., \& Mulyono, D. (2018). PROGRAM PARENTING DALAM MENINGKATKAN KUALITAS PENDIDIKAN KELUARGA. ABDIMAS SILIWANGI, 1(1), 1-8.

Atmoko, T. (2009). Partisipasi Publik dan Birokrasitisme Pembangunan. Jakarta: Jurnal Akadmeik UNSRI.

BPS Bandung Barat. (2016). Kecamatan Sindangkerta dalam Angka 2016. Bandung Barat: BPS Bandung Barat.

Direktorat PAUD. (2006). Buletin PADU Jurnal Ilmiah Anak Usia Dini. Jakarta: Direktorat PAUD.

Firmansyah, D. (2018). Analysis of Language Skills in Primary School Children (Study Development of Child Psychology of Language). PrimaryEdu - Journal of Primary Education, 2(1), 35-44. https://doi.org/10.22460/pej.v1i1.668

GJ, I. (1982). Konsep Dasar Pendidikan Anak. YOGYAKARTA: PGTKI Press.

Herawati, N. (2005). Buku Pendidikan Anak Usia Dini (p. 1). Bandung: PP.

Sastroputro. (1989). Partisipasi Komunikasi, Persuasi dan Disiplin Dalam Pembangunan Nasional. Bandung: Alami Press.

Siswanto. (1994). Pengantar Administrasi Pembangunan. Bandung: LPES.

Styarini, L. (2004). Partisipasi Anak Keluarga Miskin. Jakarta: UNJ.

Sudjiono. (2009). Konsep Dasar Pendidikan Anak Usia Dini. Jakarta: PT Indeks.

Sugiyono. (2008). Metode Penelitian Pendidikan. Bandung: Alfabeta. 